\title{
The Proliferation of Definitions of Terrorism in International Law:
}

\section{A Story of Failed Symbolism and Premature Universal Jurisdiction}

\section{Fabian Baumer-Schuppli}

\section{LLM in Human Rights Law}

\begin{abstract}
This paper analyses the proliferation of definitions of terrorism in international law and across national jurisdictions. On the one hand, this paper argues that terrorism legislation mainly pursues a symbolic function in international and criminal law by constructing the common enemy to the community of states. However, the fundamental disagreement on the nature of terrorism undermines this core function of terrorism legislation because violence becomes relativized by competing definitions of terrorism. On the other hand, this paper highlights how, in the presence of competing legal definitions of terrorism across states, the duty to prosecute or extradite (aut dedere aut iudicare) threatens the fundamental principle of foreseeability of criminal accountability (nullum crimen sine lege certa). As individuals are held accountable to multiple overlapping jurisdictions, self-determination struggles and legitimate acts in armed conflicts become increasingly criminalised. Therefore, the proliferation of definitions of terrorism in international law and across domestic jurisdictions has the effect of weakening collective action in international law and at the same time strengthening unilateral prosecution of terrorism.
\end{abstract}

Keywords: Definition of Terrorism; Symbolism; Aut Dedere Aut Iudicare; Universal Jurisdiction. 


\section{Introduction}

Hardly any other topic of criminal law is as emotionally loaded as terrorism. Consequently, domestic and international law have both embraced the concept, introducing countermeasures against terrorism. While almost everyone seems to agree that terrorism is 'bad', there is little agreement on what terrorism is. This is exemplified by a statement by the French scholar BegorreBret (2006, p. 1987) who claims that 'we must first seek an efficient response, not a precise definition'.

However, the lack of international agreement on a uniform definition of terrorism and the resulting proliferation of competing definitions on the regional and domestic level have adverse consequences for various areas of law and policy. A comprehensive overview of all consequences of the proliferation of the definitions of terrorism is beyond the scope of this paper. Instead, this paper will focus on two consequences of the proliferation of definitions of terrorism in law that have largely been neglected within academic literature.

Firstly, the proliferation of definitions of terrorism in international law has almost unanimously been portrayed as beneficial for states as it allows for flexibility in introducing counterterrorism measures while, at the same time, minimising legal constraints in the enforcement thereof (Acharya 2009, pp. 668-669; Grozdanova 2014, p. 316). Conversely, this paper argues that the proliferation of definitions of terrorism fractures the community of states and erodes the normative foundation of terrorism legislation as the community is unable to construct a common enemy.

Secondly, the delicate interplay between the proliferation of definitions of terrorism across domestic jurisdictions and the principle of aut dedere aut iudicare (to extradite or to prosecute) has remained underexplored. This paper emphasizes that the interplay between the different definitions might damage the fundamental principle of nullum crimen sine lege certa (no crime without well-defined law).

In this essay, I will first elaborate on the nature of the proliferation of definitions of terrorism in international law and across national jurisdictions. I will then highlight the importance of symbolism in terrorism legislation and explain how the competing definitions of terrorism fracture the international community. Afterwards, I will explain the principle of aut dedere aut iudicare and how the interplay between the principle and the proliferation of definitions of 
terrorism erodes fundamental principles of criminal law. Consequently, the findings will highlight how states compensate a lack of collective agreement on a definition of terrorism with the unilateral expansion of their criminal jurisdiction, to the detriment of fundamental principles of criminal law.

\section{Symbolism and the Power to Define}

For a better understanding, I will shortly outline the nature of the proliferation of definitions of terrorism in international law. While there are multiple treaties ${ }^{1}$ which enumerate specific terrorist acts on a global level, none of these treaties contain an abstract definition of terrorism. Thus, definitions of terrorism on the global level resemble a sectoral approach that can be freely adjusted to new situations and contexts (Greene 2017, pp. 415-416). With the drafting of the United Nations Draft Comprehensive Convention 2000, there have been efforts to reach an agreement on an abstract definition of terrorism (Saul 2006, pp. 184-185). However, the drafting process ultimately suffered from a stalemate when fundamentally different conceptions of terrorism became apparent among the member-states. On the one hand, certain members wanted to introduce an exclusionary clause for self-determination movements which would have prevented struggles of peoples against colonial and racist regimes and foreign occupiers from falling within the ambit of terrorism (Saul 2005a, p. 78). On the other hand, other members disagreed on the question of whether terrorism can be committed not only by non-state actors but also by armed forces belonging to a state party (ibid., p. 80).

Along with the lack of an abstract definition on the global level, there is a proliferation of different abstract definitions on the regional level. The differences among these regional treaties ${ }^{2}$ are striking and go far beyond mere semantics. Finally, the proliferation of international and regional definitions is intensified at the national level with virtually every jurisdiction having its own definition (Di Filippo 2014, p. 10). The extreme proliferation of definitions of terrorism across domestic jurisdictions accelerated with Security Council Resolution 1373 which obliged states to criminalise terrorist conduct but failed to define the concept of terrorism (United Nations Security Council 2001, art. 2(e); Saul 2005b, p. 161). Furthermore, regional conventions add to the proliferation, as states often simply have to 'approximate' the delicts described in the conventions ('Council and European Parliament Directive (EU) 2017/541' 2017, para. 6). 
However, some authors claim that the proliferation of definitions of terrorism is largely overstated and that there is in fact a definition of terrorism in customary international law (Cassese 2006, p. 957; Gal-Or 2015, pp. 698-699). Those scholars who accept the existence of a customary definition of terrorism usually point to shared elements that are common to various international and domestic definitions of terrorism (Cassese 2006, p. 957; Gal-Or 2015, pp. 686-687). The Special Tribunal for Lebanon accepted the existence of a customary law definition of terrorism based on shared elements found in various international and domestic definitions (Gillett \& Schuster 2011, p. 1007), but some scholars have dismissed the verdict of the tribunal as incomplete and motivated by judicial activism (Verdebout 2014, pp. 725-726). Indeed, an enumerative approach conceals how many definitions form a coherent whole and cannot be dissected. For example, the exclusion of self-determination struggles constitutes a fundamental component of the definition of terrorism for the signatories to the Convention of the Organisation of the Islamic Conference on Combating International Terrorism (1999, art. 2). Moreover, in light of the continued failure to reach common ground on the definition of terrorism at the global level (Braber 2016, pp. 41-43), it is hard to see how a customary definition of terrorism could have emerged (Aksenova 2015, pp. 283-284; Ambos 2011, p. 671; Saul 2011, p. 699).

The lack of harmony between the definitions of terrorism at the national and regional levels, and the absence of an abstract definition on the global level has widely been regarded as a failure of international law, as the power to define terrorism is left to states (United Nations Security Council 2001, Resolution 1373, art. 2(e); Grozdanova 2014, p. 308; Margariti 2017, p. 8; Saul 2005b, p. 160; Zeidan 2004, p. 492). Interestingly, no scholars have actually explained why it is unusual for states to have such power to define terrorism, since the power to define criminal conduct is one of the core characteristics of state-sovereignty (Baragwanath 2018, p. 27; Young 2006, p. 100) and a proliferation of definitions across countries is certainly not surprising. However, it might be that terrorism is a unique crime and a proliferation of definitions may have uniquely harmful effects. There are multiple arguments one could intuitively raise to highlight the harmful effects of a proliferation of definitions of terrorism. For example, one could ascertain that it hampers a coordinated response to terrorism (Richards 2014, p. 214; Van den Herik \& Schrijver 2013 , p. 4) or that it opens the opportunity for states to frame terrorism in terms of war (Martin 2013, p. 647) with the detrimental consequence of establishing a parallel system to criminal law which lacks its procedural safeguards (Wade 2010, p. 416). However, these issues are not unique 
to terrorism but are also common for other transnational crimes such as drug trafficking (Orlova \& Moore 2005, p. 269). I argue that it is not necessarily terrorism that differs from other crimes, but it is terrorism legislation that differs from other criminal legislation. Thus, this section focuses on an entirely different argument that has not received adequate attention: the proliferation of the definitions of terrorism undermines one of the foundational purposes of terrorism legislation, namely its symbolic function.

Terrorism legislation differs from other criminal legislation insofar as it usually does not focus on criminalizing specific harmful acts, since most conduct that is deemed terroristic in nature is already criminalized under domestic law around the world (Fletcher 2006, pp. 895-896; Weigend 2006, pp. 912-913). Saul (2006, p. 25) argues that terrorism is distinct from other crimes because of its intent to instil fear and its political motive. Yet, there is even fundamental disagreement with respect to these two characteristics (Braber 2016, p. 46). Therefore, there is a substantive overlap between terrorism and other crimes such as murder which begs the question: what is the purpose of criminalising terrorism?

One potential answer is that the criminalisation of terrorism serves primarily a symbolic function. The term 'symbolic' as it is used in this paper is neither meant in a derogatory way nor is it intended to imply that such legislation is ineffective or useless. Rather, the term emphasises that the primary purpose of the criminalisation of terrorism is labelling 'the other' or 'the public enemy' (Begorre-Bret 2006, p. 1991; Friedrichs 2006, pp. 87-90; Schmitt 1933, p. 8). While proponents of labelling theory might point out that this is no different from other crimes (Becker 2018, pp. 11-12), it is hardly disputable that the crime of terrorism takes labelling to the extreme (Bryan, Kelly \& Templer 2011, pp. 85-86). By criminalising terrorism, the state wants to demonstrate that terrorism constitutes some form of 'other' violence that is more severe than 'normal' violence (Dexter 2012, p. 132). The severity that is ascribed to acts deemed 'terrorist' is also exemplified by the expansive use of surveillance, extraordinary administrative and police powers, as well as the multiplication of precursor offences (Hamilton 2019, pp. 110-117). Therefore, states may expand their powers by defining threats and determining appropriate countermeasures (Wæver 1995, p. 54).

This holds true for both the domestic and the international level. In Resolution 1373, the United Nations Security Council (2001, preamble para. 3) labelled any form of terrorism as a threat 
to peace, irrespective of the context it is committed in or its actual impact on international security (Subedi 2002, p. 160; Saul 2005b, pp. 158-159). While domestic terrorism legislation attempts to define a threat to the community within a state, international terrorism legislation aspires to construct a threat to the community of states. Therefore, defining terrorism as a collective threat on the international level attempts to achieve an effect comparable to the goal of domestic terrorism legislation: determining and shaping a common 'enemy'.

A similar logic is exemplified by international criminal laws, where symbolic reasons are regularly invoked as justification for their existence (Aksenova 2017, p. 486; Damaska 2008, pp. 345-347). As Damaska (2008, pp. 345-347) argues, international criminal justice is most persuasive where it seeks to stigmatise inhumane acts and to build a common moral understanding. The label of an international crime such as genocide comes with enormous moral weight attached (Mayroz 2017, pp. 87-88) and arguably justifies humanitarian intervention and the use of force (Simon 2016, p. 164; William \& Stewart 2008, p. 110). Therefore, international crimes ultimately serve a discursive function of labelling the 'enemy' to the community of states, and where a common understanding emerges, collective action becomes possible. Likewise, as the main purpose of terrorism legislation rests on symbolism, the effectiveness of labelling the common 'enemy' depends on a shared understanding of what constitutes terrorism.

However, as aforementioned, international law on terrorism lacks a common understanding of what the concept of terrorism entails. Instead, terrorism law is marked by diverging definitions across states and regions. Multiple authors have asserted that the lack of a uniform definition in international law has placed states in a comfortable position of defining terrorism at will (Acharya 2009, pp. 668-669; Grozdanova 2014, p. 316; Richards 2014, pp. 214-215). However, those who claim that the power to define is solely beneficial for states fail to grasp the consequences of the proliferation of definitions on the international level. While the power to define might increase cohesion on the national level (Richards 2014, p. 214), terrorism legislation fails to define the common 'enemy' on the international level and instead relativises violence. If each state defines his enemies as terrorists and these enemies likewise define the condemning state's conduct as terrorism, then violence becomes only a matter of perspective (Begorre-Bret 2006, p. 1994; LeVin 1995, pp. 49-50; Walzer 2001, p. 17). One might very well even ask whether terrorism really exists if there can be no shared understanding of it. However, an even more drastic consequence flowing from the proliferation of definitions of terrorism is the way in which it disbands any hope of a 
world without terrorism (Herschinger 2013, p. 195). To develop a common vision of a world without terrorism presupposes a shared understanding of terrorism (ibid., pp. 194-195). The proliferation of definitions reveals that terrorism is a relative concept which in turn prevents the community of states to differentiate themselves from the 'terrorists' (ibid., p. 195). Instead, the community fractures into regional groups where a certain common understanding of terrorism can be found. However, this fragmentation imposes legitimacy costs on states because their counterterrorism measures become driven by competing and contradicting regional political agendas. Thus, the proliferation of definitions of terrorism undermines one of the core purposes of terrorism legislation: to develop a common 'enemy' and a common vision of the international community of eradicating terrorism.

\section{Universal Jurisdiction and the Proliferation of Definitions}

The conclusion drawn in the previous section has profound consequences for other areas of law. As the proliferation of definitions of terrorism undermines the normative foundation of international terrorism legislation, options for international cooperation become limited. Instead, states opt for an expansion of their unilateral powers. This can best be seen in the progressive inclusion of the principle of aut dedere aut iudicare (to extradite or to prosecute) in international (Caligiuri 2018, p. 248), regional, ${ }^{2}$ and domestic (Thalmann 2018, pp. 186-199) terrorism legislation. Multiple states apply the principle based on general clauses that give precedence to treaty obligations (ibid., pp. 161-164), even when the domestic terrorism legislation does not explicitly provide for it. Aut dedere aut iudicare overlaps with the principle of universal jurisdiction with the difference that universal jurisdiction is permissive and aut dedere aut iudicare mandatory (Kolb 2004, p. 253; Thalmann 2018, p. 74). States must amend their legislation to enable prosecution or extradition of alleged terrorists (Kolb 2004, p. 256). While traditional criminal jurisdiction is based on the principles of territoriality and nationality (Lee 2007, p. 203), universal jurisdiction allows the prosecution of a crime by any state (Thalmann 2018, pp. 67-69). By maximising the number of jurisdictions where the alleged terrorist can be prosecuted, universal jurisdiction mainly aims at preventing impunity (Lee 2007, p. 209). Interestingly, in the light of a growing consensus that the duty to prosecute precedes over the duty to extradite (Kolb 2004, p. 258; Thalmann 2018, pp. 83-84), Lee (2007 pp. 212-213) has asserted that universal jurisdiction might also facilitate a fair trial where the territorial state may be politically motivated in its judgement. 
However, there are multiple reasons why universal jurisdiction as such is a controversial concept. On the one hand, universal jurisdiction interferes with state sovereignty (Lee 2007, p. 208). On the other hand, if national jurisdictions are seen as communities that share common norms and values, fairness requires that a perpetrator is also judged by the community he or she belongs to or has committed the crime against (ibid., pp. 208-209; Perkins 1971, pp. 1155-1156). For these reasons, universal jurisdiction can in principle only be justified to prosecute the most heinous crimes, where an act does not just offend the community it has been committed against but 'shock[s] the conscience of humanity' (Rome Statute of the International Criminal Court 1998, preamble; Nagle 2011, pp. 356-357). Moreover, universal jurisdiction presupposes that there is international agreement on a precise definition of the crime (Nagle 2011, p. 357).

Some scholars dispute that terrorism fulfils these criteria and thus question whether there is a legitimate interest in universal jurisdiction over terrorism (ibid., p. 356). The various definitions of terrorism are so broad that the claim that any terrorist act is of concern to the international community is hardly defensible (ibid., p. 353). Moreover, the lack of a uniform definition of terrorism seems to violate the legal mandate that a crime must be well-defined. One might argue that certain acts of terrorism as defined by the sectoral treaties fulfil this requirement, but the multiple conflicting abstract definitions found in regional treaties cast doubt on the legitimacy to exercise universal jurisdiction over terrorism in abstract terms. Nevertheless, various authors passionately defend universal jurisdiction over terrorist crimes (Lawless 2007, p. 146; Lee 2007, p. 212; Newton 2013, pp. 84-85).

In any case, states are free to establish universal jurisdiction through treaties, as they have done with terrorism. In fact, both the United Nations Security Council and the General Assembly have contributed in a fundamental way to the current situation. The General Assembly has consistently emphasised the principle of aut dedere aut iudicare in its pre 9/11 terrorismresolutions (Lawless 2007, pp. 144-145) and the Security Council implicitly affirmed the principle in Resolution 1373 without ever defining terrorism (United Nations Security Council 2001, art. 2(c); Saul 2005b, p. 142). It was only three years later, after many states had already enacted their own terrorism legislations, that the Security Council provided an abstract definition of terrorism with Resolution 1566 (United Nations Security Council 2004, article 3) $)^{5}$. Notwithstanding, Resolution 1566 is non-binding and there is neither a duty to incorporate the definition of the Security Council nor to amend existing laws (Saul 2006, p. 248). Thus, nothing prevents states 
from exercising universal jurisdiction unilaterally over acts that fall within their domestic definition of terrorism.

Consequently, the proliferation of definitions of terrorism results in an incongruence. States may only approximate the abstract definition of terrorism found in one of the treaties. Many of these treaties even explicitly hold that nothing prevents the parties from incorporating a broader definition of terrorism in their domestic legislation (Convention of the Shanghai Cooperation Organization against Terrorism 2009, art. 2(2)). In that case, their duty of aut dedere aut iudicare only concerns those acts falling within the treaty-definition (Kolb 2004, pp. 270-271). However, states still may prosecute acts that fall outside of the treaty-definition. Thus, in that case, any individual is potentially subject to the broadest domestic definition of terrorism.

Problems regarding congruence may even arise when states do not depart from the treatydefinitions. The duty to prosecute and extradite also applies vis-à-vis third parties who are not signatories to the agreement (Mitchell 2009, ch. 2 para. 27; Scharf 2001, p. 367). Thus, states are obliged to prosecute or extradite even in cases where the terrorist act, as defined in the treaty, was committed outside of the territories of the parties to the treaty or when it is not committed by one of their nationals. ${ }^{6}$ Therefore, an alleged terrorist might be prosecuted for conduct which was not criminal in the territory he has committed the alleged act of terrorism because the exercise of universal jurisdiction usually does not require dual criminality (Thalmann 2018, p. 362). Moreover, states are not required to apply the criminal law of the state where the crime was committed (ibid., p. 365). In fact, applying foreign law in the context of universal jurisdiction is extremely rare (ibid.).

This raises fundamental questions with respect to the principle of nullum crimen sine lege certa (no crime without well-defined law). According to this principle, an individual can only be held criminally liable for his acts if it was foreseeable that his or her conduct was punishable, and the respective legal norms were accessible (Reuter 2017, p. 20; Scharf 2001, pp. 375- 376; Van der Wilt 2015, p. 530). The question of whether the exercise of universal jurisdiction violates the principle was raised in relation to torture before the European Court of Human Rights (ECtHR). In Ould Dah v. France (2009, p. 422) the complainant was convicted by the French authorities for the crime of torture he had committed in Mauritania. The ECtHR dismissed the complainant's claim that his conviction was not foreseeable and violated the principle of nullum crimen sine lege 
certa (Ould Dah v. France (dec.) 2009, p. 439). Surprisingly, the ECtHR solely focused on the precision of French law and not on the foreseeability of the application of French law to the complainant's case (Thalmann 2018, p. 233). Thalmann (ibid., p. 234) rightly points out that the judgement is unsatisfactory and the foreseeability of the application of French law was by no means self-evident as the ECtHR seemed to see it. However, what might have swayed the ECtHR was the fact that torture was not only precisely defined in French law but also in international law (Ould Dah v. France (dec.) 2009, p. 439; Convention against Torture and Other Cruel, Inhuman or Degrading Treatment or Punishment 1984, art. 1(1)).

However, the situation is quite different for terrorism. As established above, there is no coherent approach to terrorism in international law. Instead, there are the sectorial crimes in international law and multiple competing abstract definitions in regional treaties. To complicate matters further, some of the regional definitions encompass behaviour that is clearly legitimate in wartime. For example, the Convention of the Shanghai Cooperation Organisation against Terrorism (2009, art. 2(1)(3)) inter alia views acts that intend to 'intimidate the population and ... cause substantial damage to property ... in order to achieve political, religious, ideological and other aims by influencing the decisions of authorities' as acts of terrorism. Many legitimate acts in armed conflicts and self-determination struggles fall within this definition. The United Kingdom (R. v. Gul (2013) UKSC 64, paras. 52-58) and Canada (R. v. Khawaja (2012) SCC 69, paras. 95103) have convicted individuals based on terrorism offences for acts that arguably should have been governed by international humanitarian law (Roach 2014, p. 823). Whether there is a violation of nullum crimen sine lege certa must be determined on a case by case basis but under these current premises, there is an increased potential for violation. At the very least, one would need to concede that there are heavy legitimacy-costs involved and the integrity of criminal law suffers if the principle of nullum crimen sine lege certa is watered down by exercising universal jurisdiction in the absence of international agreement on a definition of terrorism.

There are, of course, multiple practical limitations on the materialisation of the aforementioned issues. First, the alleged terrorist must be present in the territory of the prosecuting state in order to trigger the aut dedere aut iudicare principle (Kolb 2004, pp. 268-269). Second, a state might not fully implement the principle despite the treaty obligation (Martin 2013, p. 664) or simply forfeit prosecution for political reasons (Kolb 2004, pp. 261-262). However, it is unsatisfactory to trust in the underenforcement of criminal law. In my view, the premature 
introduction of the aut dedere aut iudicare principle in terrorism legislation in the absence of a universal consensus on the definition of terrorism erodes the fundamental principle of nullum crimen sine lege certa in criminal law.

\section{Conclusion}

As I have shown in this paper, the proliferation of definitions of terrorism in international law and across national jurisdictions carries unintended consequences. The competition of different definitions of terrorism on the international level has fractured the international community, preventing the construction of a common 'enemy' and a common vision. Some might celebrate the fact that legislative incoherence limits state power on the international plane, while others might see it as a missed chance to challenge indiscriminate violence in a coherent way.

In any case, the proliferation of definitions of terrorism does not just undermine the sense of a shared understanding on the international level but threatens to erode fundamental and shared principles of criminal law. The introduction of the aut dedere aut iudicare principle in the absence of a shared understanding of terrorism has led to a complex system of overlapping and contradictory criminal jurisdictions which hampers the foreseeability of being held criminally liable. Thus, there is a serious danger that the application of the aut dedere aut iudicare principle undermines the fundamental principle of nullum crimen sine lege certa. The primary beneficiaries of the overlapping jurisdictions are the major international powers as it allows them to criminalize behaviour abroad that threatens cohesion at home. This is accompanied by a legislative shift to criminalize even broader concepts than terrorism such as 'extremism' (Greene 2017, p. 439).

Thus, the consequences of the proliferation of definitions of terrorism on the international level and across national jurisdictions are multi-layered with contradictory effects for legal systems, states, and individuals. States might balance the adverse consequences the proliferation of definitions has on collective actions against terrorism with more extensive unilateral competences to prosecute conduct abroad, to the detriment of fundamental legal principles. 


\section{Notes}

1. Convention on Offences and certain Other Acts Committed on Board Aircraft 1963; Convention for the Suppression of Unlawful Seizure of Aircraft 1970; Convention for the Suppression of Unlawful Acts against the Safety of Civil Aviation 1971; Convention on the Prevention and Punishment of Crimes against Internationally Protected Persons, including Diplomatic Agents 1973; International Convention against the Taking of Hostages 1979; Convention on the Physical Protection of Nuclear Material 1980; Convention for the Suppression of Unlawful Acts against the Safety of Maritime Navigation 1988; Convention on the Marking of Plastic Explosives for the Purpose of Detection 1991; International Convention for the Suppression of Terrorist Bombings 1997; International Convention for the Suppression of the Financing of Terrorism 1999; International Convention for the Suppression of Acts of Nuclear Terrorism 2005.

2. See, e.g., Convention to Prevent and Punish the Acts of Terrorism Taking the Form of Crimes against Persons and Related Extortion that are of International Significance 1971, art. 2; Convention of the Organisation of the Islamic Conference on Combating International Terrorism 1999, art. 1(2); OAU Convention on the Prevention and Combating of Terrorism 1999, art. 1(3); Treaty on Cooperation among the States Members of the Commonwealth of Independent States in Combating Terrorism 1999, art. 1; 'Council and European Parliament Directive (EU) 2017/541' 2017, art. 3; Convention of the Shanghai Cooperation Organization against Terrorism 2009, art. 2(1)(3).

3. Convention to Prevent and Punish the Acts of Terrorism Taking the Form of Crimes against Persons and Related Extortion that are of International Significance 1971, art. 5; Convention of the Organisation of the Islamic Conference on Combating International Terrorism 1999, art. 3(B)(1); OAU Convention on the Prevention and Combating of Terrorism, 1999 art. 6(4); 'Council and European Parliament Directive (EU) 2017/541' 
2017, art. 19(4); Convention of the Shanghai Cooperation Organization against Terrorism 2009 , art. 5(3).

4. See, for example, 'Council and European Parliament Directive (EU) 2017/541' 2017, art. 19(4).

5. The definition provided by Article 3 of Resolution 1566 is ' $[\ldots]$ criminal acts, including against civilians, committed with the intent to cause death or serious bodily injury, or taking of hostages, with the purpose to provoke a state of terror in the general public or in a group of persons or particular persons, intimidate a population or compel a government or an international organization to do or to abstain from doing any act, which constitute offences within the scope of and as defined in the international conventions and protocols relating to terrorism, are under no circumstances justifiable by considerations of a political, philosophical, ideological, racial, ethnic, religious or other similar nature [...]' (United Nations Security Council 2004, article 3).

6. See, for example, 'Council and European Parliament Directive (EU) 2017/541' 2017, art. 19(4).

\section{References}

Acharya, UD 2009, 'War on Terror or Terror Wars: The Problem in Defining Terrorism', Denver Journal of International Law and Policy, vol. 37, no. 4, pp. 653-679, viewed 6 August 2020

$<$ https://digitalcommons.du.edu/cgi/viewcontent.cgi?article=1253\&context=djilp $>$.

Aksenova, M 2015, 'Conceptualizing Terrorism: International Offence or Domestic Governance Tool', Journal of Conflict and Security Law, vol. 20, no. 2, pp. 277-299, DOI $10.1093 / \mathrm{jcsl} / \mathrm{krv} 002$.

Aksenova, M 2017, 'Symbolism as a Constraint on International Criminal Law', Leiden Journal of International Law, vol. 30, no. 2, pp. 475-499, DOI 10.1017/S0922156516000741.

Ambos, K 2011, 'Judicial Creativity at the Special Tribunal for Lebanon: Is There a Crime of Terrorism under International Law?', Leiden Journal of International Law, vol. 24, no. 3, DOI $10.1017 / \mathrm{S} 0922156511000215$.

Baragwanath, D 2018, 'Responding to Terrorism: Definition and Other Actions', in C EboeOsuji \& E Emeseh (eds.), Nigerian Yearbook of International Law 2017. Springer International Publishing, Cham, pp. 17-49. 
Becker, HS 2018, Outsider: Studies in the Sociology of Deviance, Free Press, New York.

Begorre-Bret, C 2006, 'The Definition of Terrorism and the Challenge of Relativism', Cardozo Law Review, vol. 27, no. 5, pp. 1987-2004, viewed 6 August 2020 $<$ https://eurasiaprospective.files.wordpress.com/2015/09/definition-of-terrorism.pdf $>$.

Braber, I 2015, 'The Thorny Nature of a Terrorism Definition in International Law', IUP Journal of International Relations, vol. 10, no. 1, pp. 40-55, viewed 6 August 2020 $<$ iupindia.in/1601/International\%20Relations/The_Thorny_Nature_of_a_Terrorism.html $>$.

Bryan, D, Kelly, L \& Templer, S 2011, 'The Failed Paradigm of 'Terrorism', Behavioral Sciences of Terrorism and Political Aggression, vol. 3, no. 2, pp. 80-96, DOI 10.1080/19434472.2010.512151.

Caligiuri, A 2018, 'Governing International Cooperation in Criminal Matters: The Role of the Aut Dedere Aut Judicare Principle', International Criminal Law Review, vol. 18, no. 2, pp. 244-274, DOI 10.1163/15718123-01802005.

Cassese, A 2006, 'The Multifaceted Criminal Notion of Terrorism in International Law' Journal of International Criminal Justice, vol. 4, no. 5, pp. 933-958, DOI 10.1093/jicj/mq1074.

Convention against Torture and Other Cruel, Inhuman or Degrading Treatment or Punishment 1984, Treaty no. 24841, United Nations Treaty Series, 1465, pp. 85-210, viewed 16 February 2020, $<$ https://treaties.un.org/doc/Publication/UNTS/Volume\%201465/v1465.pdf>.

Convention for the Suppression of Unlawful Acts against the Safety of Civil Aviation 1971, Treaty No. 14118, United Nations Treaty Series, 974, pp. 177-248, viewed 16 February 2020, <https://treaties.un.org/doc/Publication/UNTS/Volume\%20974/v974.pdf>.

Convention for the Suppression of Unlawful Acts against the Safety of Maritime Navigation 1988, Treaty no. 29004, United Nations Treaty Series, 1678, pp. 201-348, viewed 16 February 2020, $<$ https://treaties.un.org/doc/Publication/UNTS/Volume\%201678/v1678.pdf>.

Convention for the Suppression of Unlawful Seizure of Aircraft 1970, Treaty no. 12325, United Nations Treaty Series, 860, pp. 105-159, viewed 16 February 2020, $<$ https://treaties.un.org/doc/Publication/UNTS/Volume\%20860/v860.pdf $>$.

Convention of the Organisation of the Islamic Conference on Combating International Terrorism 1999, viewed 16 February 2020, <http://ww1.oicoci.org/english/convenion/terrorism_convention.htm>.

Convention of the Shanghai Cooperation Organization against Terrorism 2009, Treaty no. 49374, United Nations Treaty Series, 2815, pp. 69-142, viewed 16 February 2020, $<$ https://treaties.un.org/doc/Publication/UNTS/Volume\%202815/v2815.pdf $>$. 
Convention on Offences and certain Other Acts Committed on Board Aircraft 1963, Treaty no. 10106, United Nations Treaty Series, 704, pp. 219-254, viewed 16 February 2020, $<$ https://treaties.un.org/doc/Publication/UNTS/Volume\%20704/v704.pdf $>$.

Convention on the Marking of Plastic Explosives for the Purpose of Detection 1991, Treaty no. 36984, United Nations Treaty Series, 2122, pp. 359-420, viewed 16 February 2020, $<$ https://treaties.un.org/doc/Publication/UNTS/Volume\%202122/v2122.pdf $>$.

Convention on the Physical Protection of Nuclear Material 1980, Treaty no. 24631, United Nations Treaty Series, 1456, pp. 101-188, viewed 16 February 2020, $<$ https://treaties.un.org/doc/Publication/UNTS/Volume\%201456/v1456.pdf $>$.

Convention on the Prevention and Punishment of Crimes against Internationally Protected Persons, including Diplomatic Agents 1973, Treaty no. 15410, United Nations Treaty Series, 1035, pp. 167-248, viewed 16 February 2020, $<$ https://treaties.un.org/doc/Publication/UNTS/Volume\%201035/v1035.pdf $>$.

Convention to Prevent and Punish the Acts of Terrorism Taking the Form of Crimes against Persons and Related Extortion that are of International Significance 1971, Treaty no. 24381, United Nations Treaty Series, 1438, pp. 191-209, viewed 16 February 2020, $<$ https://treaties.un.org/doc/Publication/UNTS/Volume\%201438/volume-1438-I-24381English.pdf $>$.

'Council and European Parliament Directive (EU) 2017/541 on Combating Terrorism and Replacing Council Framework Decision 2002/475/JHA and Amending Council Decision 2005/671/JHA’2017, Official Journal L88, p. 6, viewed 6 August 2020, <https://eurlex.europa.eu/legal-content/EN/TXT/?uri=CELEX\%3A32017L0541>.

Damaska, M 2008, 'What is the Point of International Criminal Justice', Chicago-Kent Law Review, vol. 83, no. 1, pp. 329-365, viewed 7 August 2020, $<$ https://digitalcommons.law.yale.edu/cgi/viewcontent.cgi?article $=2599 \&$ context $=$ fss_pa pers $>$.

Dexter, H 2012, 'Terrorism and Violence: Another Violence is Possible?', Critical Studies on Terrorism, vol. 5, no. 1, pp. 121-137, DOI 10.1080/17539153.2012.659920.

Di Filippo, M 2014, 'The Definition(s) of Terrorism in International Law' in B Saul (ed.) Research Handbook on International Law and Terrorism. Edward Elgar, Cheltenham, pp. 3-19.

Fletcher, GP 2006, 'Indefinable Concept of Terrorism', Journal of International Criminal Justice, vol. 4, no. 5, pp. 894-911, DOI 10.1177/1477370819828934.

Friedrichs, J 2006, 'Defining the International Public Enemy: The Political Struggle Behind the Legal Debate on International Terrorism', Leiden Journal of International Law, vol. 19, no. 1, pp. 69-91, DOI 10.1017/S0922156505003183. 
Gal-Or, N 2015, 'The Formation of a Customary International Crime: Global Terrorism Human (In)Security', International Criminal Law Review, vol. 15, no. 4, pp. 665-699, DOI 10.1163/15718123-01504006.

Gillett, M \& Schuster, M 2011, 'Fast-track Justice: The Special Tribunal for Lebanon Defines Terrorism', Journal of International Criminal Justice, vol. 9, no. 5, pp. 989-1020, DOI 10.1093/jicj/mqr036.

Greene, A 2017, 'Defining Terrorism: One Size Fits All?', International and Comparative Law Quarterly, vol. 66, no. 2, pp. 411-440, DOI 10.1017/S0020589317000070.

Grozdanova, R 2014, “'Terrorism' - too Elusive a Term for an International Legal Definition?', Netherlands International Law Review, vol. 61, no. 3, pp. 305-334, DOI 10.1017/S0165070X14001351.

Hamilton, C 2019, Contagion, Counter-terrorism and Criminology, Springer International Publishing, Cham.

Herschinger, E 2013, 'A Battlefield of Meanings: The Struggle for Identity in the UN Debates on a Definition of International Terrorism', Terrorism and Political Violence, vol. 25, no. 2, pp. 183-201, DOI 10.1080/09546553.2011.652318.

International Convention against the Taking of Hostages 1979, Treaty no. 21931, United Nations Treaty Series, 1316, pp. 205-280, viewed 16 February 2020 $<$ https://treaties.un.org/doc/Publication/UNTS/Volume\%201316/v1316.pdf $>$.

International Convention for the Suppression of Acts of Nuclear Terrorism 2005, Treaty no. 44004, United Nations Treaty Series, 2445, pp. 89-198, viewed 16 February 2020 $<$ https://reaties.un.org/doc/Publication/UNTS/Volume\%202445/v2445.pdf>.

International Convention for the Suppression of Terrorist Bombings 1997, Treaty no. 37517 , United Nations Treaty Series, 2149, pp. 256-336, viewed 16 February 2020 $<$ https://reaties.un.org/doc/Publication/UNTS/Volume\%202149/v2149.pdf>.

International Convention for the Suppression of the Financing of Terrorism 1999, Treaty no. 38349, United Nations Treaty Series, 2178, pp. 197-292, viewed 16 February 2020 $<$ https://treaties.un.org/doc/Publication/UNTS/Volume\%202178/v2178.pdf $>$.

Kolb, R 2004, 'The Exercise of Criminal Jurisdiction over International Terrorists' in A Bianchi (ed.) Enforcing International Law Norms against Terrorism. Hart, Oxford, pp. 227-282.

Lawless, M 2007, 'Terrorism: An International Crime', International Journal, vol. 63, no. 1, pp. 139-159, DOI 10.1177/002070200806300112.

Lee, W 2007, 'Terrorism and Universal Jurisdiction' in S P Lee (ed.) Intervention, Terrorism, and Torture: Contemporary Challenges to Just War Theory. Springer, Dordrecht, pp. 203-217. 
LeVin, VT 1995, 'The Logomachy of Terrorism: On the Political Uses and Abuses of Definition', Terrorism and Political Violence, vol. 7, no. 4, pp. 45-59, DOI 10.1080/09546559508427317.

Margariti, S 2017, Defining International Terrorism: Between State Sovereignty and Cosmopolitanism, T.M.C. Asser Press, The Hague.

Martin, C 2013, 'Terrorism as a Crime in International Domestic Law: Open Issues' in L Van den Herik \& N Schrijver (eds.) Counter-terrorism Strategies in a Fragmented International Legal Order. Cambridge University Press, Cambridge, pp. 639-666.

Mayroz, E 2017, 'Genocide: To Prevent and Punish 'Radical Evil'’ in P Kastner (eds.) International Criminal Law in Context. Taylor and Francis, Milton, pp. 71-90.

Mitchell, C 2009, Aut Dedere, Aut Judicare: The Extradite or Prosecute Clause in International Law, Graduate Institute Publications, Geneva.

Nagle, LE 2011, 'Terrorism and Universal Jurisdiction: Opening a Pandora's Box', Georgia State University Law Review, vol. 27, no. 2, pp. 339-378, DOI 10.2139/ssrn.1582432.

Newton, MA 2013, 'Terrorist Crimes and Aut Dedere Aut Judicare Obligation' in L Van den Herik \& N Schrijver (eds.) Counter-terrorism Strategies in a Fragmented International Legal Order. Cambridge University Press, Cambridge, pp. 68-92.

OAU Convention on the Prevention and Combating of Terrorism 1999, Treaty no. 39464, United Nations Treaty Series, 2219, pp. 179-256, viewed 16 February 2020 $<$ https://treaties.un.org/doc/Publication/UNTS/Volume\%202219/v2219.pdf>.

Orlova, A V \& Moore, J W 2005, “"Umbrellas” or "Building Blocks”?: Defining International Terrorism and Transnational Organized Crime in International Law', Houston Journal of International Law, vol. 27, no. 2, pp. 267-310, viewed 7 August 2020 $<$ http://www.hjil.org/articles/hjil-27-2-orlova-moore.pdf $>$.

Perkins, R 1971, 'The Territorial Principle in Criminal Law', Hastings Law Journal, vol. 22, no. 5, pp. 1155-1172, viewed 6 August 2020

$<$ repository.uchastings.edu/cgi/viewcontent.cgi?article $=2186 \&$ context=hastings_law_jour nal $>$.

Reuter, T 2017, Judicial Practice, Customary International Criminal Law and Nullum Crimen Sine Lege, Springer International Publishing, Cham.

Richards, A 2014, 'Conceptualizing Terrorism', Studies in Conflict \& Terrorism, vol. 37, no. 3, pp. 213-236, DOI 10.1080/1057610X.2014.872023.

Roach, K 2014, 'Terrorism' in MD Dubber \& T Hörnle (eds.) The Oxford Handbook of Criminal Law. Oxford University Press, Oxford, pp. 812-837. 
Rome Statute of the International Criminal Court 1998, Treaty no. 38544, United Nations Treaty Series, 2187, pp. 3-633, viewed 16 February 2020

$<$ https://treaties.un.org/doc/Publication/UNTS/Volume\%202187/v2187.pdf>.

Saul, B 2005a, 'Attempts to Define 'Terrorism' in International Law', Netherlands International Law Review, vol. 52, no. 1, pp. 57-84, DOI 10.1017/S0165070X05000574.

Saul, B 2005b, 'Definition of Terrorism in the UN Security Council: 1985-2004', Chinese Journal of International Law, vol. 4, no. 1, pp. 141-166, DOI 10.1093/chinesejil/jmi005.

Saul, B 2006, Defining Terrorism in International Law, Oxford University Press, Oxford.

Saul, B 2011, 'Legislating from a Radical Hague: The United Nations Special Tribunal for Lebanon Invents an International Crime of Transnational Terrorism', Leiden Journal of International Law, vol. 24, no. 3, pp. 677-700, DOI 10.1017/S0922156511000203.

Scharf, MP 2001, 'Application of Treaty-based Universal Jurisdiction on Nationals of Non-party States', New England Law Review, vol. 35, no. 2, pp. 363-382, viewed 7 August 2020 $<$ heinonline.org/HOL/LandingPage?handle=hein.journals/newlr35\&div=24\&id=\&page= $>$.

Schmitt, C 1933, Der Begriff des Politischen [The Concept of the Political], Hanseatische Verlagsanstalt, Hamburg.

Simon, TW 2016, Genocide, Torture, and Terrorism, Palgrave Macmillan US, New York.

Subedi, SP 2002, 'The UN Response to International Terrorism in the Aftermath of the Terrorist Attacks in America and the Problem of the Definition of Terrorism in International Law', International Law FORUM du Droit International, vol. 4, no. 3, pp. 159-169, DOI 10.1163/157180402400497800.

Thalmann, V 2018, Reasonable and Effective Universality: Conditions to the Exercise by National Courts of Universal Jurisdiction over International Crimes, Schulthess, Geneva.

Treaty on Cooperation Among the States Members of the Commonwealth of Independent States in Combating Terrorism 1999, Treaty no. 50095, United Nations Treaty Series, 2867, pp. 41-74, viewed 16 February 2020

$<$ https://treaties.un.org/doc/Publication/UNTS/Volume\%202867/v2867.pdf $>$.

United Nations Security Council 2001, Resolution 1373, Resolution S/RES/1373, viewed 16 February $2020<\mathrm{https}: / /$ www.unodc.org/pdf/crime/terrorism/res_1373_english.pdf $>$.

United Nations Security Council 2004, Resolution 1566, Resolution S/RES/1566, viewed 16 February $2020<$ https://www.un.org/ruleoflaw/files/n0454282.pdf $>$. 
Van den Herik, L \& Schrijver, N 2013, 'The Fragmented International Legal Response to Terrorism' in L Van den Herik \& N Schrijver (eds.) Counter-terrorism strategies in a fragmented international legal order. Cambridge University Press, Cambridge, pp. 1-26.

Van der Wilt, H 2015, 'Nullum Crimen and International Criminal Law: The Relevance of the Foreseeability Test', Nordic Journal of International Law, vol. 84, no. 3, pp. 515-531, DOI 10.1163/15718107-08403007.

Verdebout, A 2014, 'La Definition Coutumière Du Terrorisme d'Antonio Cassese: De la Doctrine au Tribunal Special pour le Liban [The Customary Definition of Terrorism of Antonio Cassese: Of the Doctrine of the Special Tribunal for Lebanon]', Droit et Société, vol. 88, no. 3, pp. 709-728, DOI 10.3917/drs.088.0709.

Wæver, O 1995, 'Securitization and Desecuritization' in RD Lipschutz (eds.) On Security. Colombia University Press, New York, pp. 46-86.

Wade, M 2010, 'Fighting Terrorism - The Unprincipled Approach: The UK, the War on Terror and Criminal Law' in M Wade \& A Maljevic (eds.) A War on Terror: The European Stance on a New Threat, Changing Laws and Human Rights Implications. Springer, New York, pp. 401-427.

Walzer, M 2001, 'Excusing Terror: The Politics of Ideological Apology', The American Prospect, vol. 12, no. 18, pp. 16-17, viewed 6 August 2020 $<$ https://prospect.org/features/excusing-terror/>.

Weigend, T 2006, 'The Universal Terrorist: The International Community Grappling with a Definition', Journal of International Criminal Justice, vol. 4, no. 5, pp. 912-932, DOI 10.1093/jicj/mq1063.

William, PR \& Stewart, ME 2008, 'Humanitarian Intervention: The New Missing Link in the Fight to Prevent Crimes against Humanity and Genocide?', Case Western Reserve Journal of International Law, vol. 40, no. 1-2, pp. 97-110, viewed 6 August $2020<$ https://scholarlycommons.law.case.edu/cgi/viewcontent.cgi?article=1276\&context=jil $>$.

Young, R 2006, 'Defining Terrorism: The Evolution of Terrorism as a Legal Concept in International Law and its Influence on Definitions in Domestic Legislation', Boston College International and Comparative Law Review, vol 29, no. 1, pp. 23-106, viewed 6 August $2020<$ https://lawdigitalcommons.bc.edu/iclr/vol29/iss1/3>.

Zeidan, S 2004, 'Desperately Seeking Definition: The International Community's Quest for Identifying the Specter of Terrorism', Cornell International Law Journal, vol. 36, no. 3, pp. 491-496, viewed 6 August 2020 $<$ https://scholarship.law.cornell.edu/cilj/vol36/iss3/5/>. 


\section{Case Law}

Ould Dah v. France (dec.), ECHR 2009-I, pp. 415-466

R. v. Gul (2013) UKSC 64

R. v. Khawaja (2012) SCC 69 